Leif Östman

\title{
An explorative study of municipal developer competitions in Helsinki
}

\begin{abstract}
This paper discusses the central features of so-called 'site allocation competitions', as organized by the City of Helsinki Real Estate Department (Kiinteistövirasto in Finnish). Site allocation competitions are developer competitions where the municipality sells or leases plots of land to developers or contractors, but where the 'bidding' is based on competing on the basis of architectural and urban quality factors. The focus in this paper is on the Finnish context, but as its legal framework is constituted by European competition law. In these competitions the proprietor expects the contractor or developer to create a design team and in turn the proprietor receives multiple proposals for a site without really paying for them. It seems important to examine this rather new type of architectural competition, as it is often an integral part of important large projects in terms of both financial investments and architectural design. It also constitutes a new tool in the practices of urban planning. The present study is explorative, based mainly on a close study and analysis of written material, such as reports, as well as three interviews with experienced organizers. The aim of the paper is to clarify the concept of developer competition, and discuss its possible benefits and problems. The core issue in the study is how architectural quality is produced within the legal framework, as well as to discuss the relation of the developer competition to the aims of urban planning and professional agents.
\end{abstract}

Keywords: Architectural Quality, Developer Competition, European Competitions law, Professional agents

\section{Introduction}

The following paper discusses the central features of so-called 'site allocation competitions', as organized by the City of Helsinki Real Estate Department (Kiinteistövirasto in Finnish). Site allocation competitions are developer competitions where the municipality sells or leases plots of land to developers or contractors, but where the 'bidding' is based on competing on the basis of architectural and urban quality factors. The focus in this paper is on the Finnish context, but as its legal framework is constituted by European competition law, the basic legal principles are applicable in any European Union member state. In these competitions the proprietor expects the contractor or developer to create a design team and in turn the proprietor receives multiple proposals for a site without really paying for them. The winning contractor/developer gets the site and is then obliged to erect a building or group of buildings in accordance with the design proposal. Site allocations are civil law contracts and the seller can include specifications that would not be possible according to the planning regulations of the Finnish Land Use and Building Act.

It seems important to examine this rather new type of architectural competition as it is often an integral part of important large projects in terms of both financial investments and architectural design. It also constitutes a new tool in the practices of urban planning. As the city administration in Helsinki has been the strongest actor and promoter of developer competitions in Finland, I decided to examine their current procedures as a typical model in organizing developer competitions. I will present their aims and trace how architectural quality is described and evaluated. One of the main tasks of the Helsinki Real Estate Department (hereafter simply Real Estate Department) is to allocate suitable building sites to interested parties in accordance 
with politically defined principles (mainly for housing purposes). In 2011 the total value of all land sold was €34, 6 million but Helsinki favours municipal land ownership with $62 \%$ of the land still in the hands of the city, producing an annual total of $€ 188,9$ million in land rents.

The present study is explorative, based mainly on a close study and analysis (Johansson Lindfors 1993) of written material, such as reports, as well as three interviews with experienced organizers. The aim of the paper is to clarify the concept of developer competition, map its development, and discuss its possible benefits and problems. The core issue in the study is architectural quality as seen from the perspective of professional architects, but I also think it is important to understand the legal framework, as well as discuss the relation of the developer competition to the aims of urban planning and professional agents.

The paper starts with an analysis of the concept and its relation to competition law and other types of competition. In the second section I present some background information, the process, core factors and the basis for the assessment of the results of some developer competitions organized by the Real Estate Department. The final section is devoted to a discussion about differences in interest distribution among agents within this field, raising the questions of where to position these competitions within the framework of urban planning policies, and whether it is a complement to or replacement of certain imperfect instruments of urban planning.

\section{Methodological considerations and approach}

This study is based on an investigation of existing legislative regulations and case law regarding competition, a study of reports about developer competitions, mostly limited to the Finnish context, a case study of three developer competitions based on a close reading of competition programmes and competition protocols, together with three interviews of relevant professionals. There is already quite a mass of literature on real estate development, but almost all of it is focused on how to make money by investing and managing real estate. I have not found any research-based reports on developer competitions with regard to architectural design and very little regarding land use transactions. There is some literature and research on architectural competitions. Also, the field of construction contracts is quite mature, with a large variety of contract forms.

The accompanying case study is conducted as a multiple case study with a comparative character (Yin 1984 p. 47ff and p. 133ff), but with the main aim of exploring the concept of developer competitions within the context of the Helsinki urban planning and real estate market. The process consisted of an initial interview (Haapanen \& Kivelä 2012), combined with a search for and analysis of material regarding competition programmes and protocols. This was followed by a study of competition reports and a selection of cases that can be compared in a productive way, resulting in a comparison of the statements about urban planning and architectural quality within competition programmes and protocols. The findings are compared with current literature and aim at explanation-building with reference to three central units of analysis: competition principles, planning authority and risk taking (Yin 1984 p. 107ff).

In studying the general field of land sales and leasing in relation to developer competitions in Finland, the only known research is two surveys (Kiinteistövirasto 2007, Kauppinen \& Ervola 1997). I have analyzed the material from the actual competitions, but do not want to draw too many conclusions about architectural quality from them. I noted that one of the informants described the jury process as a series of praise of all entries but still ending in the selection of one winner, indicating that it is not easy to follow the logic of the verbal quality assessments of the professional jurors (Haapanen \& Kivelä, 2012). I want to underline 
that this is in line with my understanding of aesthetic judgment, meaning that it is never possible to construct a valid verbal description of architectural qualities and that professional competence appears as a tacit but still valid experiential conclusion about values and misfits. Aesthetic judgment must be based on sense-based experiences of the architecture. The (professional) eye becomes the judge. It is possible to point out qualities and indicate where the values are in architecture. The architectural quality is demonstrated, though not fully articulated. Lundequist claims that we do not try to describe what good architecture is, but rather we select examples and indicate what should be seen as important qualities (1998). This is expressed by Bourdieu, finding support in Wittgenstein, in saying that concepts used to judge art display an extreme indeterminacy, making verbal characterizations of qualities difficult (Bourdieu 1996, p. 296). The Swedish law on public procurement includes a specific chapter on project competitions (in Swedish projekttävlingar) and a section regarding jury protocol; the law is limited to the ranking of the tenders, thus avoiding the problem of describing the qualities of each proposal (Lag om offentlig upphandling, 2007, Chap. 14).

The interviews with Sami Haapanen, currently head of the Real Estate Department, and Tuomas Kivelä, recently retired from a position responsible for the organization of developer competitions, were conducted as discussions with a few open questions, but with a focus on the process. In the interview with Harri Kauppinen, retired development manager at the Real Estate Department, the focus was on the historical development of competition practices (Kauppinen, 2012). All interviewees have read and commented on a draft version of the present paper.

Despite my research interest devoted to the perspective of professional architects, it is beyond the scope of the present paper to analyze realized architecture or to analyze how to counteract land speculation and its negative effects, which, of course, is a core interest of the City of Helsinki as the cost of land increases the housing costs. The main idea here is to provide a structured insight into this matter which would allow for more scrutiny and analysis, and hopefully improvements to the system in the long run.

\section{Positioning}

I think it is important to clarify the position of this type of competition in regard to stakeholders, competition law and contract forms. It is important to see the relations to risk taking and the production of urban quality, the latter being a central target for society, alongside cost competitive housing production. These competitions seem to be most interesting in areas where there is a great difference between market prices for housing units and production costs, typically areas where the production of new building land is limited and the demand is great. This indeed has long been the case in Helsinki (Haapanen \& Kivelä, 2012).

The name in Finnish for this special type of developer competition has in general been 'tontinluovutuskilpailu', which I would translate as 'site allocation competition'. However, I will use the term 'developer competition'. In Sweden it is called 'markanvisningstävling', and in Germany the name 'Investorenwettbewerb' or 'Bauherrenwettbewerb' seems quite common. The Real Estate Department has recently tried a shift towards calling them 'laatukilpailu' - i.e. literally 'quality competition' - but as a more generalized concept I think they should be called 'developer competition'. In a developer competition the developers constitute competitors, and by means of agreements with architects they produce design entries that constitute their potential bid. The normal site allocation competitions at the Real Estate Department are developer competitions, with a given land price and conducted as design and construct quality bidding, where the construction phase is the total responsibility of the contractor (perustajaurakointi in Finnish). To avoid additional cost compensation 
claims from the developer/contractor, the Real Estate Department must not interfere by introducing new conditions or changes after the competition and the contract is signed (Haapanen \& Kivelä, 2012). In these 'total responsibility contracts' the developer/contractor must organize both financing and the selling of the apartments. The competitions are often open to both building contractors and developers, but typically the proposals are prepared in cooperation between an architect and a housing developer, with no in-house building contractor.

In comparison to a conventional architectural competition, the developer competition is based on cooperation between an architect and developer/contractor. The idea is that the building contractor can improve the design with his knowledge of production methods and cost efficiency. In a conventional architectural competition the architect has a free hand in the design and the competition programme is the only limiting factor. The client might conduct a cost estimate in connection with the assessment process but the influence of contractor competence is applied after bidding on final drawings, and the contract is normally a contract with shared responsibilities between the client and developer/contractor. The competitions in both cases can be restricted or open competitions but this does not change the basic differences. In a survey based on interviews with 13 developers/contractors in Stockholm, Remnås and Norrman (2003) conclude that developers/contractors - especially smaller companies - tend to see developer competitions as costly. The normal format for the selling of municipal land is a contract with mutual responsibilities, normally including responsibility for the construction of infrastructures by the developer/contractor (Boverket 2005, Eerolainen 2005).

The normal procedure in the majority of cases in the selling or leasing of land in Helsinki for housing projects is to sell or lease a site to a developer/contractor who then hires an architect and designs and constructs according to an assessment of market demand. In this case the Real Estate Department is just trading for money, and quality aspects are guided by the master plan and the local building authority within the framework of the Land Use and Building Act (1999). In large projects the Real Estate Department assigns land to a developer and includes a contract statute demanding that the developer organizes an architecture competition. In an analysis of the potential conflict with competition law regarding site allocation contracts, in a report from the Swedish National Board of Housing, Building and Planning (2005) the authors found it questionable to include contract agreements according to which the counterpart (contractor) is obliged to construct infrastructure for a development as part of a site allocation contract, if it is a public contract outside open competition (Boverket 2005 , p. 16), as this poses a limitation to open competition.

All these different types of bidding and forms of contract provide different distributions of risks and costs for design, bidding, administration, supervision and selling. In the developer competition the developer will take the market risk for construction and selling and will invest in the design, with the risk of not getting the contract. I have not investigated the cost distribution between architect and developer/contractor in the tendering phase, but assume they use some kind of cost/risk sharing scheme.

In a conventional architectural competition the architect alone invests in the design, with a high risk of getting no financial return, especially in popular open competitions. In these cases the contractor risks little and it is the client who carries the risk of losing control of the project budget as there is no cost control in the concept design stage. On the other hand, in normal housing projects it is the developer/contractor who invests in design and carries the risk. The architect then takes little economic risk and the Real Estate Department does not have to invest much time in the process (Kiinteistövirasto, 2007). 
It is important in studies regarding such elements as 'architecture' or 'urban quality' to make an analysis of stakeholders and their interests (Lipstadt, 2010). First of all, this is about creating a more objective relation to the object of study and interests involved. Secondly, I think it is important as a means to understand the logic of these processes, especially if we assume that there are also values other than money at stake. I think most professionals act according to professional values but also to cost benefits, and political commitments to urban development are often tied to quality aspects, too. Urban development is a complex field of professional and political values in combination with the realization of business interests and contract practices.

The central agent here is the Real Estate Department, backed by political strategies and the City Council. Their business processes are clearly profitable (Kiinteistövirasto, 2011). The goals are defined in the City Strategy Programme as "Quality and quantity of housing and versatility of the urban environment secured" (City of Helsinki, 2013). The housing market is split between more or less non-profit developer organizations and commercial developers/contractors. The non-profit developers have to take responsibility on behalf of future tenants, who are mostly selected on a social basis and with limited income, whereas the developers/contractors act in the commercial market and with profitable business as their central goal. The architects and other consultants act as business entrepreneurs but tend to adhere to professional values and peer opinions (Östman 2005, p. 119ff). In the field of housing there are also tenants but they are normally absent in these processes and enter the field only after the buildings are completed. On the other hand, we also have the public and the press who tend to take an interest in urban development and react to bad quality work in the overall urban situation, whereas the tenants supposedly take most interest in the closer living environment, the dwelling and its qualities. Another important agent seems to be the town planning agency, which is clearly responsible for the urban space and its elements. Its employees in the administration act in accordance with the professional values of architects (Karsimus \& Koivulehto, 2012), with no immediate dependence on business interests, but guided by political interests.

\section{Competition law}

In recent years the professions, including architects, have been forced to see their established professional legitimacy and business conditions eroded by European competition law, thus inflicting upon the historical legitimacy of professionals (European Commission, 2004, p.19f). The Commission sees regulatory restrictions in the professions as harmful and would like to see 'those restrictions reviewed and, where they are not objectively justified, removed or replaced by less restrictive rules'. There is an acceptance of the specific value of the services provided by 'liberal professions' such as architects, but also a 'tension between, on the one hand, the need for a certain level of regulation in these professions and, on the other hand, the competition rules of the Treaty' (Ibid). The European competition law states (European Parliament, 2004, section 46):

Contracts should be awarded on the basis of objective criteria which ensure compliance with the principles of transparency, non-discrimination and equal treatment and which guarantee that tenders are assessed in conditions of effective competition. As a result, it is appropriate to allow the application of two award criteria only: 'the lowest price' and 'the most economically advantageous tender'.

There is a case law concerning a development contract in Germany with a ruling from the European Court of Justice stating that a developmental contract for a site is not to be seen as a 
public work contract (European Court of Justice, 2010) and thus not dependent on public procurement legislation. In fact the site allocation is clearly aimed at constructing housing, but not for the agency providing the land. This is also seen as being the case at the Real Estate Department in relation to national regulations about public procurement (Haapanen, 2011). According to Haapanen, it is however advisable to organize the site allocation processes according to the principles of the Act on Public Contracts (2007, section 2):

(1) Contracting authorities shall make use of the existing competitive conditions, ensure equality and non-discriminatory treatment among all participants in the procurement procedure and act in a transparent way while meeting the requirements of proportionality. (2) Contracting authorities shall endeavour to organise their procurement procedures as economically and systematically as possible, in as appropriate combinations as possible, taking environmental considerations into account. In order to reduce administrative work involved in procurement, contracting authorities may employ framework agreements and joint procurement or make use of other partnership opportunities available in awarding public contracts. If the candidate or tenderer is another contracting authority or a community or institution which is owned by the contracting authority, it shall be treated equally alongside other candidates or tenderers.

The above legislation indicates that the processes should be transparent, treating tenders equally, but notably also 'taking environmental considerations into account'; and that social housing developers co-owned by the municipality must not be given any privileged status.

The aim of the Finnish Competition Act (2011) is 'the protection of sound and effective economic competition from harmful restrictive practices', and further states that 'special attention shall be paid to the protection of the operating conditions of the markets and the freedom of undertakings to operate so as to allow customers and consumers to benefit from competition'.

The practices of the Finnish Association of Architects (SAFA) regarding competition have been under scrutiny with reference to the competition law, forcing SAFA to reform its rules for competitions and, for example, allowing other parties to arrange competitions open to its members (Finnish Competition Authority, 2004).

Another aspect of the competition law is that it is questionable whether municipalities may assign plots to interested parties at a price level below the market level (European Commission (1997). Perhola (2000) finds, with support from several examples of Finnish case law, that it is not legally acceptable to sell plots at a price lower than $25 \%$ below the estimated market price, because it violates equal rights issues among both citizens and companies. This indicates that the municipality has to ask for a market price for the plots, regardless of how they assign it to interested parties, and of course, it is important to provide any interested and capable partner access to the bidding and assignment process.

The directive on public procurement prohibits undertakings that prohibit competition (2004, Article 2): Contracting authorities shall treat economic operators equally and nondiscriminatorily and shall act in a transparent way.

According to some decisions by the Finnish Competition and Consumer Authority (1996/418, Sallinen 2007, 321), the municipal site allocations are undertakings in accordance with the Competition Act.

Social and environmental concerns are acceptable within the framework of European Competition Law, according to Pedersen (2011, p. 139ff). Basically, contracts can be awarded according to 'the one that is most economically advantageous as a whole' (Act on Public Contracts 2007), but Case Law environmental concerns can be used if they: 
- $\quad$ are related to the objectives of the contract

- do not allow the authority an unlimited freedom of choice

- $\quad$ are mentioned in the tendering process

- $\quad$ conform with the principles of the Community Law

The judgement of the European Union Court states clearly that the assessment of a tender need not be based on purely economic grounds because other grounds can have an impact on the competition as well (C-513/99, section 55). Falk (2011, p. 395) states that it is possible to use aesthetic criteria as assessment criteria, but it must be relevant to the object of tendering.

\section{Municipal responsibilities}

We must also consider the responsibilities of the municipal agents, because there is, of course, another legislative framework parallel to the competition law regarding the purpose of administrative actions. In Finland it is the Finnish Local Government Act that regulates the organization of all cities and municipalities, stating that: 'Local authorities shall strive to promote the welfare of their residents and sustainable development in their areas' (2007, section 1, stage 3 ). The real estate management is the responsibility of the municipal real estate engineer (Real Estate Engineer Act 1995, 1 section), and his/her responsibilities are provided by the Land Use and Building Act and other legislation regarding the formation and registration of real estate (Ibid., section 3). The first section of the Land Use and Building Act (1999) states that the general objectives of the Act are:

to ensure that the use of land and water areas and building activities on them create preconditions for a favourable living environment and promote ecologically, economically, socially and culturally sustainable development and to ensure that everyone has the right to participate in the preparation process, and that planning is high quality and interactive, that expertise is comprehensive and that there is open provision of information on matters being processed.

In section 5 of the Act there is a detailed list of objectives for land use planning related to the above objectives. In chapter 13, 'Assigning and Expropriating Land', there are technical specifications regarding compensations for expropriation but no specific objectives for the real estate engineer (Land Use and Building Act, 1999).

There seems to be no independent objectives for the real estate management in a municipality mentioned in the legislation, but rather they are to be derived from the Finnish Local Government Act and the Land Use and Building Act, and by decisions taken by the local government. The real estate management should thus promote the welfare of the citizens, sustainable development and create a favourable living environment with highquality planning and expertise. There remains the question of which department should be in charge of the development. According to the first part of section 20 of the Land Use and Building Act (1999):

The local authority shall take charge of land use planning and building guidance and control within its territory. The local authority must have sufficient resources and expertise available for these functions. If the local authority's population is greater than 6000 , it must have a planner who is qualified to manage the local authority's planning functions.

This indicates that it is the qualified planner who is to be in charge of the land use planning and building guidance, governed by the political bodies. 
Private partnership planning constitutes an alternative model for urban developments, which according to a report from RAKLI (an interest organization of property investors in Finland) could be used to introduce a stronger market-oriented approach, saving costs in the administration (Kuronen, 2011). The report also claims that there is a potential for increased profit, increased profit-oriented decision making, and faster production of land for construction use, which has been a problem for Helsinki for many years (Säteri, 2012). Most of these claims, however, lack valid research data and the proposal must, I think, be seen as an attempt to open the site allocation processes to more business-oriented practices.

\section{Site allocation competitions in Helsinki Background}

The idea of developer competitions connected to municipal site allocation processes is rather new. The manager of development of the City of Helsinki Housing Production Department (ATT) Harri Kauppinen presented the idea at a seminar arranged by RAKLI in the early 1980s, but was met with harsh criticism and rejection. However, a few years later the organizers of a housing fair in Jyväskylä contacted Kauppinen about the idea and he was also, some time later, asked by the head of ATT, Marttinen, to develop his ideas (Kauppinen, 2012). The first actual realizations of developer competitions came about in 1985 with a row of terraced housing in Jyväskylä, and through ATT with housing in Kumpula, Helsinki. There were only four developer competitions organized in Helsinki up until 1990 (Kiinteistövirasto, 2012, p. 12), organized in different ways and evaluated in a survey among participating parties (Kauppinen \& Ervola 1991). The number of such competitions increased during the following years to a frequency of 2-4 each year, depending on size (Haapanen \& Kivelä, 2012), and they spread to other cities, too.

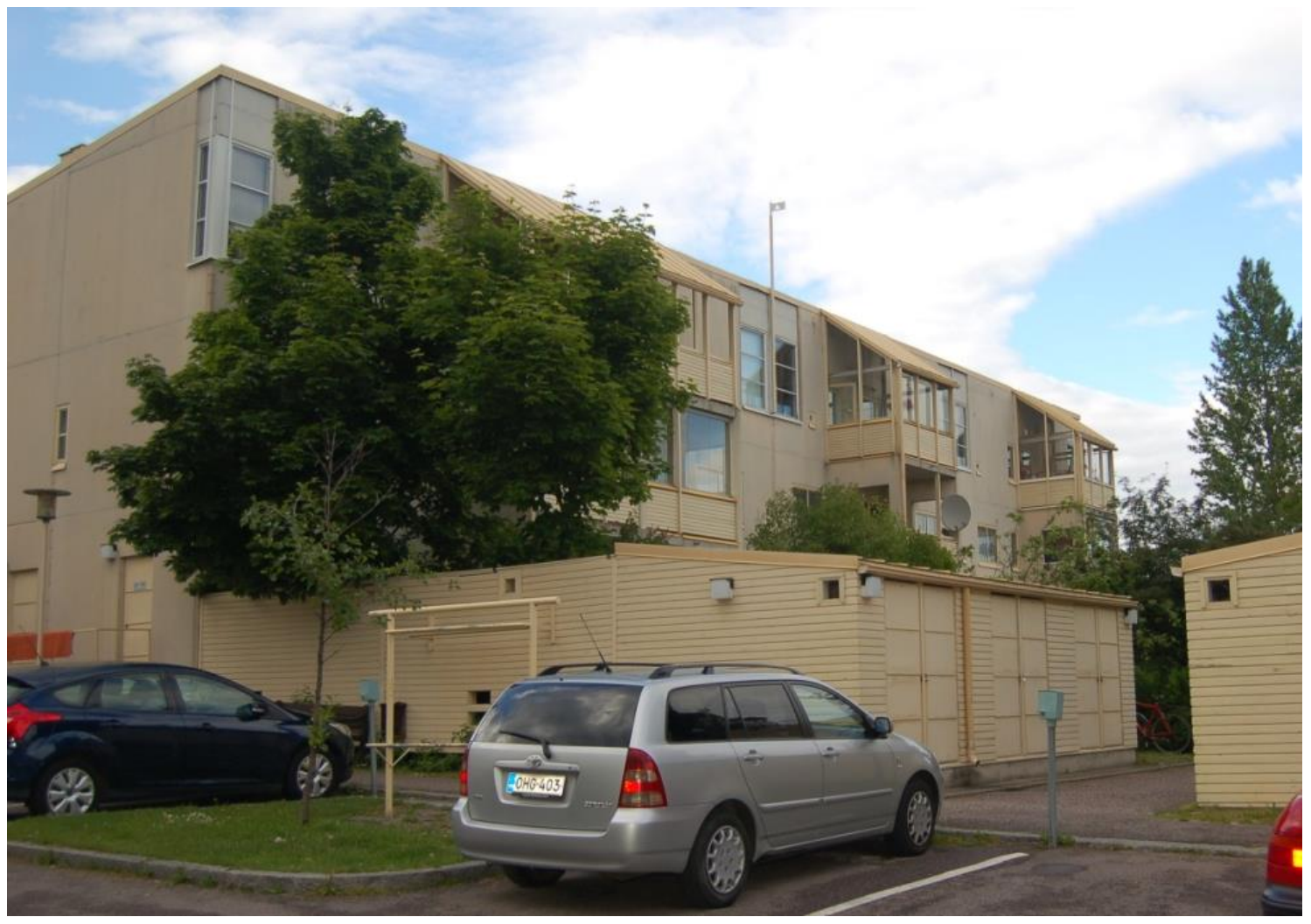

Figure 1: Kumpula housing, Helsinki. 
The testing of different variations continued (Ibid). At ATT they soon realized that it was not their task to organize developer competitions, as they themselves were a developer (Kauppinen, 2012). Thus the responsibility - and ATT's development manager Kauppinen shifted to the Real Estate Department. Cooperation with the Planning Department continued and the Arabianranta development and Kamppi Centre were two big projects realized as developer competitions (Haapanen \& Kivelä, 2012).

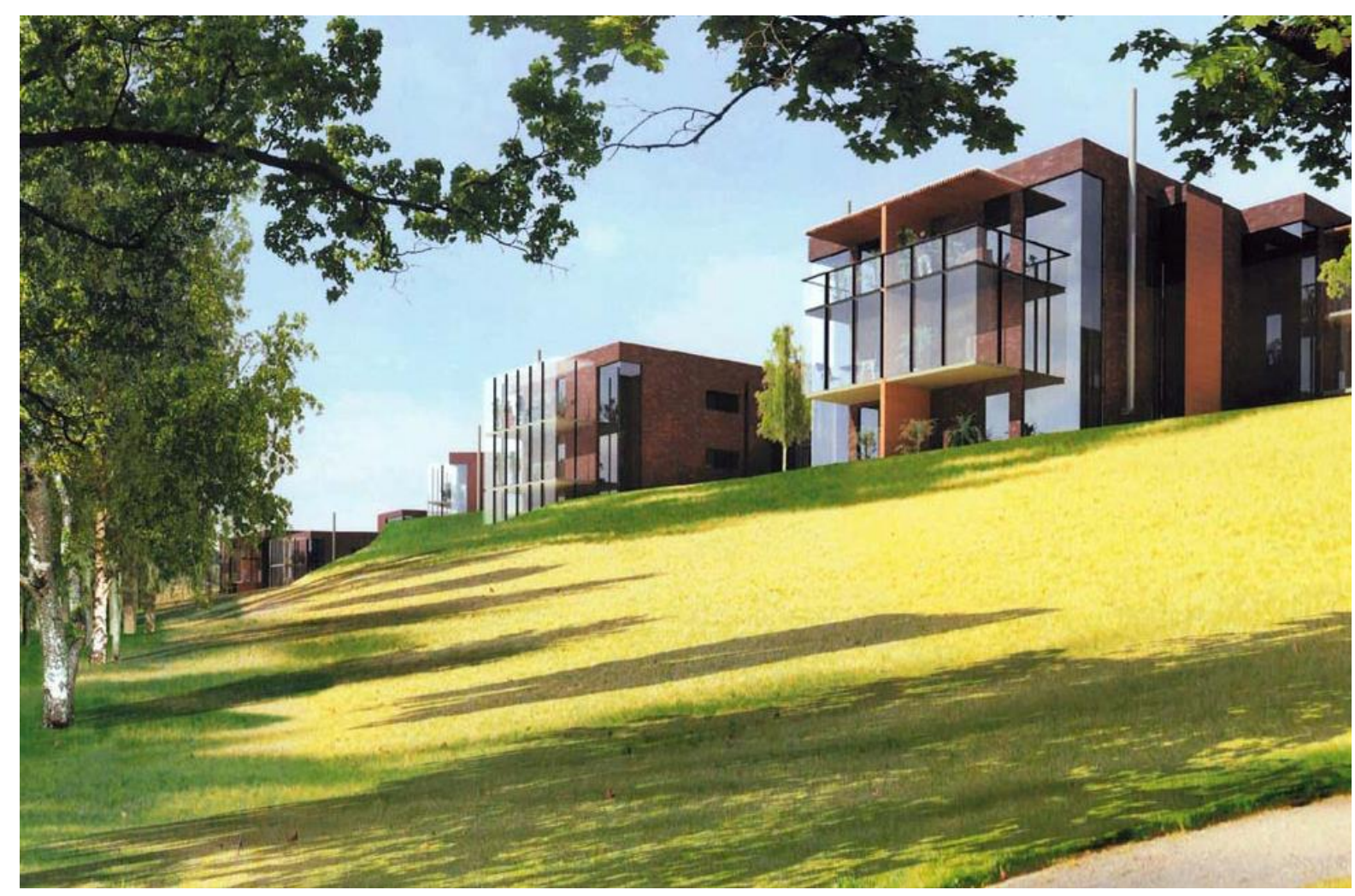

Figure 2: Image from the competition for housing at Viiki Latokartano, Helsinki, 2006.

The development continued with experimental projects such as the Lehtovuori area of detached houses and the Viiki area with a focus on ecology. Most of the developer competitions seem to have taken place within the framework of the HITAS system, a scheme in Helsinki for the production of moderate-price privately owned homes (Kiinteistövirasto, 2011). Recent projects also include developer competitions for cooperative housing and market price private homes (Haapanen \& Kivelä, 2012).

There have also been attempts to include social housing developers, based on the governmental financing scheme managed by the Housing Finance and Development Centre of Finland (ARA), but due to the complicated structure of its processes this system has proved unsuitable (Ibid). 


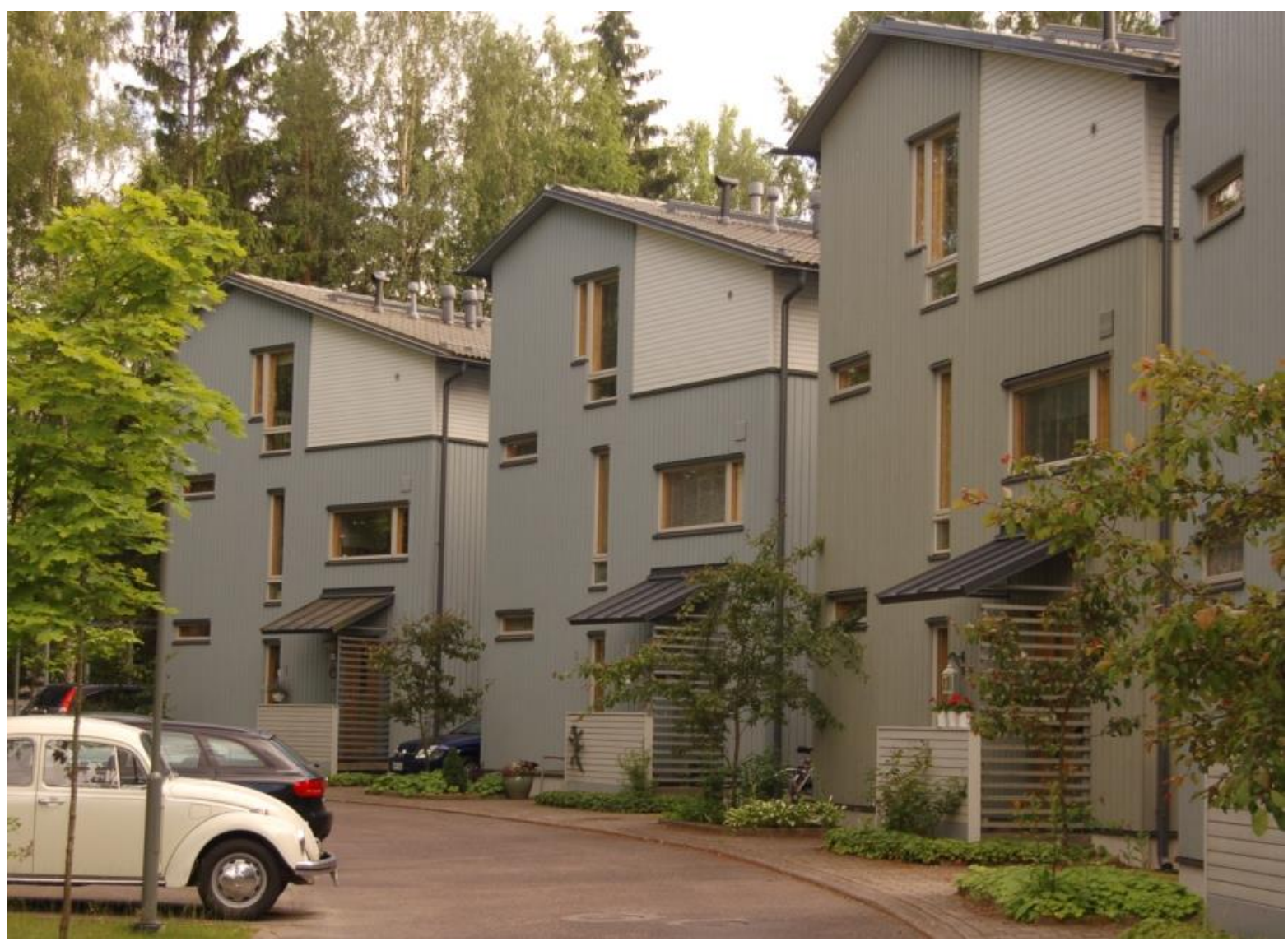

Figure 3: Street view in Lehtovuori, Helsinki.

According to Haapanen (2012), there are a few typical issues that are important in developer competitions:

- A given market-oriented price for the plot

- Competition open to any capable agent

- $\quad$ Standard type competition programmes and assessment teams

- $\quad$ Competition about architectural quality only

- Developer or contractor-led design teams

- Realization by means of 'total responsibility contracts'

The sole use of the Finnish language in all documents and the complexity and size of the projects limit the number of potential participants. According to Haapanen, the number of entries varies from zero to about a dozen (Haapanen \& Kivelä, 2012). Haapanen and Kivelä (Ibid) also emphasized the problems experienced stemming from trials based on a mix of both quality and price evaluation criteria, where it is much easier to come to an agreement if there is only one of the criteria in use. The developer competitions are widely accepted among participants in the competitions (Kauppinen \& Ervola, 1991; Kiinteistövirasto 2007, p 12).

I have selected three Helsinki case studies for an analysis of the typical content of developer competitions. I will describe the general layout of each of the competition programmes and some contract details, as well as the assessment reporting. The selection represents different types from the year 2009. The first is a HITAS project in Arabianranta (2009a); the second, Sörnäistenranta (2009c), is also a HITAS project, but also includes a site with market-priced apartments; and the third, Borgströminmäki (2009d), is a project where the 
master plan is developed according to the outcome of the competition as a test project for 'partnership-planning' (Kumppanuuskaavoitus in Finnish). The competition programmes are 25-30 pages with additional material delivered after a registration period, including master plan documents and a construction agreement specimen. The programmes are organized around four distinct topics:

- General information about the developer competition and the plot

- $\quad$ Specifications for the competition regarding architecture

- $\quad$ Organisation of the assessment

- $\quad$ Regulations about the realization of the winning entry

I will here limit my analysis to the topic of architecture, and more precisely to the assessment criteria and the organization of the competition jury, as most of the other issues are concerned with practical matters and regulations provided by the master plan. The assessment is done by a so called 'assessment team', not a jury. The assessment team is composed of 6-8 people, with one invited independent architect - similar to the independent juror in the SAFA architecture competition rules (Finnish Association of Architects, 2008) - one or two architects from the Planning Department, a chairman from the Real Estate Department and one or two other nonarchitect officials from the city administration. The architect members of the assessment team are selected in conveyance with proposals from the Planning Department, and normally there is a rotation, with different architect members of the assessment team in each competition (Haapanen \& Kivelä, 2012). The assessment team is formally selected by the political-party-based Real Estate Commission (Ibid). SAFA is not at all involved in this process.

The assessment criteria in all competitions display similar features, starting with: "in the assessment of the entries the following factors will be taken into account" (Kiinteistövirasto, 2009; 2009a; 2009b). There are some variations between the competitions, adjustments for projectspecific factors regarding the urban situation, and the need for shared spaces or innovation, but in general the assessment criteria are very general and with no weighting between the factors - often with an added emphasis that the entries will be assessed only according to qualitative criteria.

The entries are to be submitted anonymously, using a pseudonym, and in some cases, when thought necessary, includes, along with a first sealed envelope containing the competitor's details, a second sealed envelope containing information about the competitor's potential to fulfil the contract requirements (Haapanen \& Kivelä, 2012).

\section{The process}

Typically, the initiative for a developer competition comes from the City of Helsinki Planning Department, with proposals for how to proceed with land use development when the master plan has been accepted (Haapanen \& Kivelä, 2012). Starting from this premise, the Real Estate Department then makes a proposal for a plot to the City Board. Normally the competition programme is written in cooperation between the project architect, who is responsible for the planning project in question and who will propose criteria governing the design quality and planning principles, and an official from the Real Estate Department who will define contract specifications. The competition programme is checked by the assessment team and formally accepted by the Real Estate Commission (Haapanen \& Kivelä, 2012).

The competitions are open to any party that can provide the necessary resources, normally a cooperation between an architect and a contractor or developer. The programme is written in Finnish but in principle the competition is open to international developers. There is normally a period of 3-4 months for the competitors to develop and draw up entries, including an opportunity to ask anonymously clarifying questions (Haapanen \& Kivelä, 2012). 
The assessment team meets 4-6 times to evaluate the anonymous entries. The major assessment work is done by a core team, in which the architect members of the assessment team normally prepare a preliminary assessment report with quality statements about each entry. The assessment statements and the final selection of the winner are presented to the assessment team at the last meeting. Normally the assessment team agrees unanimously on the choice of the winner, although formally the head of Real Estate Department and the Real Estate Commission decide. The results are then made public and the Real Estate Department prepares contracts for the winning party, including statutes about the selling or renting of the site and the realization of the winning proposal, based on drawings and specifications (Ibid).

After the contract is signed the design is detailed for a building permit; but before they can apply for a permit the drawings must be accepted by the assessment team (Haapanen \& Kivelä, 2012). The remainder of the realization is steered by the building permit authority, with no further supervision on behalf of the Real Estate Department. Formally they could still claim that the contractor has violated the contract if the latter changes the design solution too much from the specifications attached to the contract (Ibid). The assessment report constitutes the reference for possible claims of violation (together with drawings and specifications), indicating the most important qualitative features (Ibid). The drawings and solutions will inevitably change during the detailing process.

According to the Real Estate Department's 2007 survey (Kiinteistövirasto 2007) those who have been involved in developer competitions seem satisfied with both the format and the current number of competitions. However, it is obvious that the responses acquired would depend on which position the respondent holds. I will discuss this later, but for now I will pick out a few facts from the material. The estimated cost of price-based bidding processes is $€ 65,000$ for developers. The total cost of developer competitions is estimated to be $€ 210,000$ - $€ 525,000$ and in negotiation-based processes for buying land approximately $€ 90,000$ (normal procedure). Contractors favour open price competition, without any attached architectural design aspect, whereas the non-profit developers dislike them (Ibid). Both the architect firms and the planning department officials (consisting mainly of architects) favour the idea of architectural competition as an integral part of the site allocation process (Ibid). According to the 2007 survey (Ibid.), those respondents holding a political office do not show any clear preferences. A survey by the Royal Institute of British Architects (RIBA) showed that the average cost for bidding on design competitions published in the Official Journal of the European Union was approximately $€ 6000$ with an average success rate of $31 \%$, indicating that the bidding cost was almost $€ 20,000$ per winning bid for the architect firms (Royal Institute of British Architects, 2012).

\section{The Assessment}

According to Haapanen (2012), it is important that the assessment statement includes a basic description of each entry, as it constitutes a central contractual factor. I have analyzed three competitions (ranging from 2-13 entries and with a total of 27 entries) and their assessment reports. All three reports begin by listing and describing the most important factors in 6-8 lines. The list of criteria would typically include the following:

- The architectural quality of the whole

- The quality of the building in relation to the cityscape, its integration within the environment and the architectural quality of the facades

- $\quad$ Functionality and amenity of the spatial solutions of the properties

- $\quad$ Spatial distributions of the dwellings 
Here I will limit my analysis to the external architecture and statements about urban quality. In the Arabianranta competition there is very little about the urban quality of the winning entry mentioned in the assessment report, other than: "The position of the building as the end point of Brysselinkatu street is emphasized by the overhangs of the shared spaces on the roof and by the bold brick relief surface" (Kiinteistövirasto, 2009b, 4.3). There were, in fact, only two other entries in the competition, and in comparison to the two other entries, the architecture is characterized as "clean, with the external envelope having a simple shape" (Ibid). In contrast to this, it was assessed that "the location of the buildings at the end of Brysselinkatu street has not in this case inspired the author to emphasise the composition" (Ibid, 4.1 and 4.2). The architecture in these both situations was seen as acceptable. The final selection was formulated in a single sentence ( $1 \mathrm{bid}, 5.1)$ : "The assessment team decided to select the entry "OIVA" as the winner of the competition and the entry "AURUM" as runner-up.'

The Sörnäistenranta competition attracted only two entries, where "the dense block concept turned out to be demanding; both entries have, however, managed successfully to solve this challenge and produce a totality with a good quality townscape' (Kiinteistövirasto, 2010, 3.1). The general assessment concluded that the difference in quality was found in the 'design of the dwelling" (Ibid).

The Borgströmienmäki competition involved an area of blocks split into different categories. In total there were 19 entries, each entry choosing to deal with different blocks, and with four winning entries selected (Kiinteistövirasto, 2009e). Here I will focus my analysis on the two blocks that received most entries. The plots reserved for social housing with government funding by ARA attracted less entries (Ibid). The winning entry in category 1, named 'Oskarin oksat', with 63 dwellings, was characterized as follows: 'The beautiful proposal is convincing, freshly distinctive, and carefully studied and presented' (Kiinteistövirasto, 2009e, 3.4). The entry fulfilled the regulations of the preliminary master plan, the report stating that "the scale of the facades and the layout of the windows are promising, confidently handled and beautiful" (Ibid). The architecture was described as follows: "The cubic shape of the buildings constitutes a clear base for the colourful corner bay windows that protrude out from the dominant orientation, and also the top-floor terraces are logically cut into the envelope of the building, thus emphasising the mass of the building. The colourful bay windows create with simplicity a unique expressive identity and genius loci" (Kiinteistövirasto, 2009e, 3.4.1). In category 2 the architecture of the winning entry, 'Claviuksen kellot', was characterized as follows: 'The proposal takes a strong stance regarding the cityscape and inspires positive ideas. The basis solution is freshly unconventional and creates the potential for dwellings with plan solutions that stand out positively, while on the other hand it strongly limits the designs of the neighbouring buildings" (Ibid., 3.4.2).

The assessment team's statements highlight the most important qualities of the exterior architecture and the schemes' contributions to the quality of the urban environment. I have here only quoted short sections of the comments; they remain, however, rather short and their value as specifications seem very limited. There are no clarifying statements why one entry is seen as better than the other.

\section{Conclusions}

\section{Competition Principles}

There seems to be no legal problems with the organization of site allocation competitions in the form of developer competitions and with the claim that it is even more in line with the legislation than conventional site allocation procedures based on negotiations or selling by means of fixed prices. Furthermore, the developer competition also addresses environmental 
concerns, which is in line with the goals of the Act on Public Contracts (2007, section 2) and the Land Use and Building Act (1999, section 1), and thus addresses quality development better than normal price competitions, assuming that the developer competition includes an adequate quality assessment procedure.

Compared to open architectural competitions, the developer competitions attract far fewer entries, obviously due to the limited number of contractors or developers with the capacity for the mostly large projects. There seems to be no need for restricted competitions, and moreover the representatives of the Real Estate Department have indicated an interest in the involvement of international developers so as to enhance the competition (Haapanen \& Kivelä, 2012).

Developer competitions, as currently organized by the Real Estate Department, seem to be a useful procurement method producing an improved living environment quality at a rather low cost to the city administration. Compared to the conventional methods of selling and leasing sites, the developer competition requires a competition programme and an assessment team, though the writing of a programme seems to be standardized. It seems that the real additional cost stems from the assessment process, but 4-6 meetings with 6-8 experts seems to be an acceptable additional cost for improving quality.

In a market it is acceptable to leave it to the bidders to organize their bids and to carry the additional costs for any unsuccessful bidding, but it is of course also a question of the actual use of time and production of material and thus some form of bidding compensation could smooth the way and open the competitions to more bidders, especially for important yet small sites. This could create a more competitive tendering market for site allocations.

The competition organization seems to be well established, with productive cooperation between the Planning Department and the Real Estate Department, but there remains the question of whether it is correct to have these processes organized under the Real Estate Commission. This is an especially critical point with planning partnership competitions, as the management of the land use planning responsibility belongs to the qualified planner (Land Use and Building Act, 1999, sect. 20). When looking at the competition process, it is not a problem that the assessments are so vague. According to studies by Rönn (2010), the typical jury process is one of ranking and selecting a winner, to find the best solution. It would, however, be important to state the main qualities of the winning entry as these qualities are part of the later contract. It is, of course, also necessary that the selection process of the architect members that form the core group of the assessment team is transparent, and how the professional competence of these core members comes into force and on what grounds. It is also important that the public administration is clear about planning policies and values. It would be beneficial to study the successes of developer competitions and what could be seen as appropriate quality measurements, even if it might ask for a substantial preparatory search for an appropriate research methodology.

\section{Planning and Building Control}

We have here a field with a complex combination of interests; societal- and political-based environmental values, a law-based demand for efficiency and transparency, professional interests of different kinds, and different parties with interests in reducing risk taking and maximizing profit. It seems clear that both contractors and architects have to be profitable in order to survive. The Real Estate Department must stick to market prices in its site allocation processes and preferably remain profitable. The non-profit organizations need not necessarily produce profit but are normally expected to sustain their business without external financial input. The interesting point is whether the developer competition is in balance in relation to 
each party's interests and responsibilities, and whether there are important limitations or weaknesses to it.

Normally urban development is realized step by step as individual building projects, guided by master plans and the local building control authority which approves building permits and carries out supervision during the construction of the building. As I have presented above, the processes of the developer competition have been evolving during the last 25 years and this is paralleled by the emergence and use of detailed master plan specifications (Rakennustapaohje in Finnish) which receive their real impact only in connection with site allocation contracts. This is legal in accordance with a civil contract agreement and thus there can be requirements included in contracts that are not possible in the normal master plan regulations, according to current case law (Miljöministeriet, 2003). One recent example of this is the inclusion of more rigid energy-saving and heating system requirements $^{1}$ (Stadsplaneringen, 2011). I find these two new factors attractive, contributing to the quality of urban space and the living environment, but think it would be reasonable to have some administrative guidelines regarding their use. These new methods can, however, also be seen as questioning the current system of urban planning and building supervision and its functionality in regards to the objectives of the Land Use and Building Act. It is obvious that the administration has seen it necessary to impose more rigorous conditions on builders in order to achieve a good enough quality. This produces obstacles and additional costs to the price of a dwelling - and the detailed planning regulations have been criticized by developers and contractors in Helsinki (Martinkauppi, 2009). Jani Nieminen, the CEO of the developer VVO, estimates that the planners' demand for 'diversity in form' costs approx $250 € / \mathrm{m}^{2}$ (Pyykkönen, 2012), in the Helsinki area.

With reference to the above analysis and the idea of partnership planning site allocation competitions, I think we must pose the question about the legitimate right to authorship in urban planning. Traditionally master plans are based on ideas originating from the planning architect and filtered through public reviewing and political decision making. The plan can be prepared many years before the client decides to design a building for the site and it is difficult to anticipate the needs and interests of the clients and their architect. We have here a tension between the conditions provided by the society and the (aesthetic) ambitions of the individual client. The partnership planning process can offer a solution to this, offering the client an opportunity to influence the regulation of the site but also weakening the position of the planners as they are confronted with concrete proposals and arguments. The developer competition with an assessment team constitutes a mediating agency and improves the situation by means of competing entries and a assessment that is competent yet distanced from the original stance of the city's town planner.

\section{Positions and Risk Taking}

I conclude the discussion by assessing the different positions and risks involved in the field of municipal developer site allocation competitions regarding urban and architectural quality. In regard to quality, I find the competition interesting as it clearly constitutes a stance taken by the municipal administration, where architectural quality is emphasized and where the developers/contractors are forced to focus on architectural quality in the project acquisition process. It is true that the architect consultant is forced into a very commercial relation compared to a conventional architectural competition, but compared to a normal commission from a developer or contractor the architect here still has the competition programme and the assessment team supporting his/her work and safe-guarding a certain level of architectural quality. The present study does not really provide clarity regarding the interpretation of 
quality as an appropriate condition for the assessment of 'effective competition', but there is a need for more research on this subject.

Interestingly enough, we have here also two other parties who have to take stronger responsibility for the design management process. The developers will certainly rely on the services of the hired architect but due to the coming quality assessment process they will have to combine their business and production optimization efforts with an assessment of the quality of the architect's production. The conventional situation of given master plan regulations and building permit process is one where any solution that fulfils the requirements must be approved, which makes it much easier to assess the feasibility of a proposal, where tacit professional dimensions of architectural quality must not be considered too much. The Real Estate Office is also (in a broader sense) engaged in this design process.

There is a considerable economic risk here for the architects and the developers, which makes it difficult for non-profit developers to participate because they can hardly distribute a series of unsuccessful bidding costs on to other projects (Haapanen \& Kivelä, 2012), which is possible in a business practice of a developer/contractor and a normal procedure in their acquisition practices. The relatively low financial turnover of architects' offices compared to that of the contractors, makes it seem reasonable to assume that the contractor carries most of the risk of the bidding.

Finally, I think, looking at the results from the Real Estate Department 2007 survey (Kiinteistövirasto 2007), that there is a clear distribution of interests according to professional positions - making a calculation of average opinions useless and unreliable. It is clear that there exists a legitimate request for urban planning and development leadership and that it must be managed by the representatives of the democratic society and its administration, and with a primary focus on urban and living environment quality. The aim of the administration is to organize this in an efficient and transparent way, based on open competition principles and clear assessment statements, potentially combined with descriptive material from the competition entries. In regard to the design practices of today, it seems reasonable to include software-based models as part of the presentation formats and assessment reports, allowing a better articulation of architectural and urban qualities, providing more transparency and legitimating awarded contracts.

\section{Leif Östman}

Ph D, Principal lecturer and Architect

Department of Construction Engineering,

Novia, University of Applied Sciences, Vasa, Finland

Email: leif.ostman@novia.fi 


\section{References}

\section{Legislation}

Administrative Procedure Act (Unofficial translation) 434/2003. Available at: www.finlex.fi

Act on Public Contracts (Unofficial translation) 30.3.2007/348. Available at: www.finlex.fi

Competition Act (Unofficial translation) 948/2011. Available at: www.finlex.fi

European Commission (1997). Commission Communication on State aid elements in sales of land and buildings by public authorities. Official Journal C 209, 10/07/1997 P. 0003 - 000. Available at: eur-lex.europa.eu

European Parliament (2004). Directive 2004/18/EC of the European Parliament and of the Council of 31 March 2004 on the coordination of procedures for the award of public works contracts, public supply contracts and public service contracts

Finnish Local Government Act (2007). Helsinki: The Association of Finnish Local and Regional Authorities

Lag om offentlig upphandling (2007). Available at: www.notisum.se

Land Use and Building Act 132/1999, amendment 222/2003 included (Unofficial translation). Available at: www.finlex.fi

Miljöministeriöt (2003). Handledning 12. Beteckningar och bestämmelser i detaljplaner. Helsingfors: Miljöministeriöt. Available at: http://www.ym.fi/sv-FI/Aktuellt/Publikationer

Real Estate Engineer Act 1995. Available at: www.finlex.fi

\section{Books and reports}

Bourdieu, Pierre (1996). The Rules of Art. Genesis and Structure of the Literary Field. Stanford (CA): Standford University Press.

Boverket (2005). Markpolitik och kommunala markpriser - En undersökning av hur 13 kommuner arbetar med markprissättning och markanvisning vid överlåtelse av mark för bostadsändamål. Kalrskrona: Boverket.

City of Helsinki (2013). Strategy Programme (short version). Helsinki: City of Helsinki.

Eerolainen, Jussi (2005). Maankäyttösopimukset - aitoa kumppanuutta?

European Court of Judgment (2010). Judgment of the Court, Case C-451 108.

European Court of Judgment (1999). Judgment of the Court, Case C-513/99.

Falk, Jan-Erik (2011). Lag om offentlig upphandling - en kommentar. Stockholm: Jure

Finnish Association of Architects (2008). Competition Rules. Helsinki: Finnish Association of Architects.

Finnish Competition Authority (2004). Output limitation in application of architectural competition conditions. Dnro 669/61/02, 11 October 2004.

Finnish Competition Authority (1998). Asuntoalueen vuokrasopimukseen sisältyvä velvoite liittyä kaukolämpöverkostoon. Dno 418/61/96, 15.4.1998.

Haapanen, Sami \& Kivelä, Tuomas (2012). Discussion on site allocation procedures (Personal communication, 28 June 2012).

Haapanen, Sami (2011). Käytännön näkökulmia asuntotonttien luovuttamiseen kilpailulla. (Unpublished presentation 10.11.2011). Helsinki: City of Helsinki.

Johansson Lindfors, Maj-Britt (1993). Att utveckla kunskap. Om metodologiska och andra vägval vid samhällsvetenskaplig kunskapsbildning. Lund: Studentlitteratur.

Karsimus, Outi \& Koivulehto, Leila (eds.) (2012). Kaupunkisuunnitteluviraston toimintasuunnitelma vuosille 2012-2014. Helsinki: Kaupunkisuunnitteluvirasto.

Kauppinen, Harri (2012). Discussion on site allocation procedures (Personal communication, 30 June 2012). 
Kauppinen, Harri \& Ervola, Kirsti (1991) Tontinluovutuskilpailut. Helsinki: Asuntotuotantotoimisto.

Kaupunginvaltuusto (2009). Strategiaohjelma 2009 - 2012. Helsinki: Helsingin kaupunki, Kaupunginvaltuusto.

Kiinteistövirasto (2011). Kiinteistöviraston toimintakertomus. Fastighetskontorets årsberättelse. 2011. Helsinki: Helsingin kaupunki, Kiinteistövirasto.

Kiinteistövirasto (2011b). Mikä HITAS on? Helsinki: Helsingin kaupunki, Kiinteistövirasto.

Kiinteistövirasto (2007). Kyselytutkimus Helsingin Kaupungin asuntotonttien luovutustapojen kehittämiseksi. Helsinki: Helsingin kaupunki, Kiinteistövirasto.

Kuronen, Matti (2011). Julkisjohtoinen alue- ja projektikehitysyhtiö. Loppuraportti 1.9.2011. Helsinki: RAKLI.

Lipstadt, Hélène (2010). Experimenting with the Experimental Tradition, 1989-2009: On Competitions and Architectural Research. In: Rönn, M. Kazemian, R. \& Andersson, J.E. (eds.) The Architectural Competition. Research, Inquiries and Experiences. Stockholm: Axl Books.

Lundequist, Jerker (1998). Arkitektur; etik = estetik. Stockholm: Kungliga Tekniska Högskolan.

Martinkauppi, Kirsi (ed.) (2009). Rakentamisen normitalkoot - turhat kustannukset kuriin. Ympäristöministeriön raportteja 10/2009. Helsinki: Ympäristöministeriö.

Remnås, Maria \& Norrman, Stefan (2003). Byggherrekostnader - En analys. Stockholm: KTH

Pedersen, Kristian (2011). Upphandlingens grunder - en introduktion till offentlig upphandling och upphandling i försörjningssektorerna. Stockholm: Jure.

Perhola, Kai (2000). Tonttien alennusmyyntikampanjat kunnissa. Espoo: Teknillinen korkeakoulu.

Pyykkönen, Marko (2012). VVO:n Nieminen: Rakentamisen kalleus estää kohtuuhintaisen vuokra-asumisen. Rakennuslehti 4.7. 2012.

Rönn, Magnus (2010). Architectural Policies, Regulation and Jury Dilemmas in Architecture. In: Rönn, M. Kazemian, R. and Andersson, J.E. (eds.) The Architectural Competition. Research, Inquiries and Experiences. Stockholm: Axl Books.

Royal Institute of British Architects (2012). Procurement survey 2012. Available from: www.architecture.com [Accessed 6.10.2012]

Sallinen, Sini (2007). Kunnan itselleen ottamat tehtävät ja niiden oikeudelliset reunaehdot. Tampere: University of Tampere Press.

Shusterman, Richard (2000). Pragmatist Aesthetics. Living Beauty, Rethinking Art (second edition). Lanham: Rowman \& Littlefield Publishers.

Stadsplaneringen (2011).Toukovuori. Rakentamistapaohje, Toukovuoren-alueen asemakaava ja asemakaavamuutos. Alustavat rakennustapaohjeet. 20.9.2011. Borgå: Borgå stad.

Säteri, Helena (2012). Metropolialueen tontti- ja asuntotutanto - faktaa. Helsinki: Ympäristöministeriö.

Yin, Robert K. (1984). Case Study Research. Bevely Hills (CA): Sage Publications.

Östman, Leif (2005). A Pragmatist Theory of Design. The Impact of the Pragmatist Philosophy of John Dewey on Architecture and Design. Stockholm: School of Architecture.

\section{Competition programmes and protocols}

Kiinteistövirasto (2009a). Arabianrannan tontinluovutuskilpailu. Tontit 23100/51 ja 54. Kilpailuohjelma 26.5.2009. Helsinki: Helsingin kaupunki, Kiinteistövirasto.

Kiinteistövirasto (2009b). Arabianrannan tontinluovutuskilpailu, Toukoranta, tontit 23100/51 ja 23100/54. Tontinluovutuskilpailu 26.5.2009 - 30.10.2009. Arvostelupöytäkirja. Helsinki: Helsingin kaupunki, Kiinteistövirasto.

Kiinteistövirasto (2009c). Tontinluovutuskilpailu Sörnäistenniemen korttelissa no 10582 24.11.2009. Helsinki: Helsingin kaupunki, Kiinteistövirasto. 
Kiinteistövirasto (2010). Sörnäistenniemen tontinluovutuskilpailu. Arvostelupöytäkirja 12.5.2010. Kortteli 10582. Helsinki: Helsingin kaupunki, Kiinteistövirasto.

Kiinteistövirasto (2009d). Kruunuvuorenrannan Borgströminmäen tontinvarauskilpailu. Kilpailuohjelma 28.4.2009. Helsinki: Helsingin kaupunki, Kiinteistövirasto, tonttiosasto.

Kiinteistövirasto (2009e). Borgströminmäen arvostelupöytäkirja. Helsinki: Helsingin kaupunki, Kiinteistövirasto, tonttiosasto.

\footnotetext{
${ }^{1}$ In the detail plan for Skaftkärr, with an emphasis on energy efficiency, the site allocation includes a requirement that certain specifications are to be met and in accordance with contract requirements.
} 